\title{
Theofilos
}

A Nordic open access journal in Theology, Philosophy and Culture

Published by NLA University College - in partnership with Johannelund School of Theology

Available at www.theofilos.no

\section{Populismens existentiella dimensioner Sverigedemokrater och kyrkor i den flytande moderniteten}

\author{
Joel Halldorf \\ Docent i kyrkohistoria, Enskilda Högskolan, Stockholm \\ joel.halldorf@ehs.se
}

\begin{abstract}
Rightwing populism is characterized by critique of immigration, but populist parties also address existential anxieties of late or liquid modernity. I argue that regular churchgoers reject the Sweden Democrats not only because they hold different opinions on immigration, but also due to their strong social capital. The latter helps them cope with modern anxieties, and this makes them less inclined to accept the message of the populists.
\end{abstract}

Nyckelord: Populism, Socialt kapital, Sverigedemokraterna, Kristna väljare, Frikyrkor

\section{Introduktion}

$\mathrm{I}$ Sverige representeras högerpopulistisk politik framför allt av Sverigedemokraterna, som i dag är landets tredje största parti. ${ }^{1}$ Likt andra högerpopulistiska partier talar de ofta och gärna om kristendomens betydelse för nationen - ändå har de påfallande lågt stöd bland väljare som regelbundet firar gudstjänst. ${ }^{2}$ I forskningen lyfts som främsta orsak till detta att Sverigedemokraterna är ett invandringskritiskt parti som hyllar etnisk och nationell homogenitet, medan till exempel frikyrkliga som grupp har en positiv syn på såväl mångfald som invandring. ${ }^{3}$ Denna analys ligger också i linje med uppfattningen att invandringsmotstånd är den avgörande faktorn bakom högerpopulistiska partiers väljarstöd.

Denna artikel ifrågasätter inte att detta är centralt, men vill komplettera och fördjupa analysen. För samtidigt som invandringskritik är ett viktigt inslag i Sverigedemokraternas politik, finns även andra faktorer. En del studier pekar på socioekonomiska faktorer och menar att högerpopulismen främst får stöd bland de som ibland kallas "globaliseringens förlorare". ${ }^{4}$ Andra har visat att populistiska partier i sin retorik framför allt lyfter fram kulturella och existentiella teman. ${ }^{5}$ Detta gäller också Sverigedemokraterna, som talar om vikten av traditioner, nationen som ett hem och betydelsen av gemenskap i samhället. Min tes är att de härmed adresserar en underliggande oro eller ångest som har med det senmoderna tillståndet att göra - men som en del väljare har en tendens att projicera på invandring och mångkultur. Det handlar om rotlöshet och längtan efter en plats, ett hem och nära gemenskaper. Ur detta perspektiv framstår högerpopulismen som en politisk reaktion på de stora kulturella och sociala förändringar som lett till en utbredd existentiell otillfredsställelse i moderniteten. ${ }^{6}$

Högerpopulismen samspelar alltså 
med den existentiella alienation som en rad teoretiker menar kännetecknar det moderna samhället.7 Sociologen Zygmund Bauman kallar senmoderniteten för liquid modernity eftersom han menar att den upplöser allt: institutioner, traditioner, gemenskaper, sociala nätverk, och så vidare. Detta skapar möjligheter, men är också existentiellt utmanande. ${ }^{8}$ Högerpopulistiska partiers erbjudande om större soliditet $\mathrm{i}$ form av en homogen nationalstat, bromsad globalisering och en mer likriktad kultur kan ses som ett budskap som adresserar just denna oro.

I denna artikel analyserar jag kyrkligt aktiva väljare i Sverige. Jag menar att ett skäl till att de inte attraheras av högerpopulismen är att de har en rad existentiella behov tillgodosedda genom gudstjänster, kristen tro och församlingsliv. Församlingsengagemang ger dem också ett starkare socialt kapital vilket, förutom att det motverkar den alienation som kan prägla livet i den flytande moderniteten, också ger visst socioekonomiskt skydd. Att detta får dem att avvisa auktoritär politik följer Alexis de Tocquevilles teori om den moderna demokratin. Han menade att ett vitalt civilsamhälle var avgörande för att demokratier skulle undvika atomisering, fragmentisering och till sist en utveckling mot ett auktoritärt tyranni. ${ }^{9}$

Artikeln driver med andra ord två teser. Den första är att populismen delvis är en reaktion på senmodern rotlöshet och alienation, och den andra att ett av skälen till att relativt få kyrkligt aktiva röstar på sådana partier är att de är mindre utsatta för denna typ av alienation tack vare sin förankring i ett kristet civilsamhälle med församlingsliv, gudstjänster och kyrkliga traditioner. ${ }^{10}$

\section{Moderniteten som trauma}

I sin uppmärksammade bok Age of Anger argumenterar den brittisk-indiske författaren Pankaj Mishra för att inträdet i moderniteten är ett trauma i den västerländska historien. De uppbrott moderniseringen krävde var omvälvande, och följdes för hundra år sedan av revolutioner, inbördeskrig och världskrig. Motståndet var starkast hos dem som upplevde sig utestängda från löftet om frihet och välstånd. I dag är, menar Mishra, både den växande högerpopulismen och den islamistiska extremismen symptom på samma trauma. ${ }^{11}$

Detta är ett annorlunda sätt att skriva västerlandets historia. Standardberättelsen handlar annars om hur alla kurvor pekat uppåt: tillväxt, levnadsstandard, medellivslängd och så vidare. Men om detta var allt som fanns att säga om vår tid finns inget skäl till missnöje, utan historien borde verkligen - som Francis Fukuyama hävdade - ha nått sitt slut år 1989 då muren föll.12 Givetvis finns det fog för en del optimism, för historien om det moderna Väst är förvisso en berättelse om stora framsteg vad gäller teknik, ekonomi och demokrati. Men det finns även andra sidor, och Mishras berättelse handlar om dem. ${ }^{13}$

Kulturellt och existentiellt var inträdet i moderniteten ett trauma. Framväxten av ett industriellt, kapitalistiskt samhälle ryckte människor ur deras traditionella sammanhang: lokala band, kulturella seder och religiösa traditioner. Naturligtvis kan sådana vara snäva och förtryckande, men de gav ändå en plats, en mening och en riktning i livet. Nu står vi utan de traditionella formerna för detta. Möjligheten att forma sitt eget liv har kommit på bekostnad av rötter. ${ }^{14}$

Diskussioner om modernitetens föroch nackdelar har förts sedan dess gryning under 1700-talets upplysning. ${ }^{15}$ Redan tidigt varnade somliga för att det 
moderna samhället skapade rotlöshet, oreda och själviskhet, medan andra hävdade att det gick hand i hand med utveckling, frihet och möjligheter. För de senare var den moderna världens hjälte den självständiga människan som drivs av en stark vilja och ett klart förnuft, förverkligar sig själv och gärna blir rik på köpet: the self made man. ${ }^{16}$ Men filosofen Jean Jacques Rousseau hörde till dem som protesterade mot detta ideal. Framsteg och upplysning ledde inte, hävdade han, till frihet utan till slaveri. Kommersen skapade ytlighet och konkurrensen förpestade mänsklig gemenskap: "Verklig vänskap, uppskattning och förtroende förvisas från människorna. Avundsjuka, misstänksamhet, rädsla, kyla, reservation, hat och bedrägeri ligger ständigt dolt under den uniformen". ${ }^{17}$

Flera av 1800- och 1900-talens mest inflytelserika tänkare har fortsatt diskussionen, och många av dem hävdar att modernitetens framsteg har ett existentiellt pris. Karl Marx talade om den moderna arbetarens alienation. Friedrich Nietzsche om den liknöjda och bekväma "sista människan" som bara ville ha trygghet och bekvämlighet - dessutom profeterade han att detta ordnade samhälle snart skulle gå under i en dionysisk eld. ${ }^{18}$ Sigmund Freud diagnostiserade vår vantrivsel i kulturen. Den tyske sociologen Max Weber liknade moderniteten vid en järnbur. ${ }^{19}$ Émile Durkheim beskrev det moderna tillståndet som präglat av anomi: en förvirrande laglöshet. Hanna Arendt menade att den moderna massmänniskan kännetecknades av isolering och en brist på normala relationer.20 Simone Weil rasade över den moderna staten som samtidigt kräver kärlek och dödar allt som är värt att älska, medan den brittiska författaren Rebecca West funderade på vad det tidiga 1900-talets stora europeiska krig sa om den västerländska moderniteten. ${ }^{21}$

Detta sista är en relevant fråga, för den här diskussionen rör inte bara filosofiska funderingar utan högst konkreta politiska händelser. Europas väg in i moderniteten är kantad av en rad katastrofer. Kraften i den antimoderna frustrationen blir tydlig vid första världskrigets utbrott. Kriget välkomnades som en väg till autenticitet och ut ur det moderna samhällets konstlade, byråkratiska tillvaro. Freud lät hälsa att hela hans libido stöttade ÖsterrikeUngern, och Weber hyllade detta "underbara" krig. Många drömde, med Nietzsche, om att den verklige mannen åter skulle bli herre över affärsmannen. Det vanliga är att se krig och andra storpolitiska händelser som ett resultat av materiella orsaker, som kamp om resurser och ekonomi. Men de kan också betraktas ur en existentiell synvinkel, och ses som ett resultat av ett visst kulturellt klimat.

Historiker har frågat varför Sverige undkom inbördeskrig, krig och stora revolutioner kring år 1900 trots att vår ekonomiska utveckling var svag, vilket kunde fött såväl bitterhet som folklig frustration. Slutsatsen i 1970-talets stora forskningsprojekt om de svenska folkrörelserna var att vi hade dessa rörelser att tacka för det. Här utövades den konst att sammansluta sig som Tocqueville menade var nödvändig för att forma ett stabilt modernt samhälle. Arbetarrörelsen, nykterhetsrörelsen och frikyrkorna fungerade som ett slags krockkuddar för moderniteten. De mildrade traumat och genererade på så sätt en stabilare politisk utveckling. ${ }^{22}$

När flera av samtidens mest inflytelserika författare kommenterar vår egen tid återkommer analyser som liknar Mishras. I storsäljaren Sapiens skriver den israeliske historikern Yuval Harari: 
"Individens befrielse har ett pris. Många av oss sörjer nu förlusten av starka familjer och lokalsamhällen och känner oss alienerade och hotade av den makt som den opersonliga staten och marknaden har över våra liv.”23 Den amerikanske statsvetaren Yuval Levin uttrycker sig på samma sätt: "In liberating many individuals from oppressive constraints, we have also estranged many from their families and unmoored them from their communities, work, and faith." 24

Här utkristalliserar sig en bild av moderniteten som präglad av alienation och existentiell rotlöshet, vilket påverkar politiken från 1800-talet och fram till vår flytande modernitet. ${ }^{25}$ Detta är också det teoretiska ramverket för denna artikel. Orsaken till alienationen är att människan inte lever av ekonomisk tillväxt allena, utan också har behov av gemenskap, sammanhang och traditioner. ${ }^{26}$ Flera gamla former för detta undermineras eller försvinner helt $\mathrm{i}$ och med inträdet $\mathrm{i}$ moderniteten, men några lever kvar och en del nya uppstår: folkrörelser - inklusive frikyrkor - föreningsliv, civilsamhälle och så vidare. Politiska partier kan också erbjuda alternativ med existentiella dimensioner. Socialdemokraterna gjorde det under 1900-talet, när de lanserade folkhemmet: en politisk vision som inte bara handlade om ekonomi, utan också om trygghet, tillhörighet, sammanhållning och något meningsfullt att sträva tillsammans mot. ${ }^{27}$ Men i dag är det inte minst Sverigedemokraterna som använder ett existentiellt språkbruk, när de lanserar nationen som den frälsare som ska rädda oss från den senmoderna alienationen. ${ }^{28}$

\section{Sverigedemokraternas framväxt och genombrott}

Sverigedemokraterna bildades år 1988 och flera av grundarna kom ur den nyna- zistiska rörelsen. Den förste partiledaren, Anders Klarström, var tidigare medlem i det nazistiska Nordiska rikspartiet och en annan av partiets pionjärer var Gustaf Ekström, som under andra världskriget varit med i Waffen-SS. Genom dessa rötter skiljer sig Sverigedemokraterna från de flesta andra europeiska högerpopulistiska partier. Sedan mitten av 1990-talet har partiet emellertid arbetat aktivt för att tvätta bort den rasistiska och nazistiska stämpeln, och i stället presentera sig som ett respektabelt socialkonservativt, högerpopulistiskt parti. ${ }^{29}$ I dag faller de väl in under Cas Muddes definition högerpopulism. Mudde menar att radikala populistiska högerpartier kännetecknas av att de är auktoritära, nativistiska - det vill säga betonar vikten av nationell homogenitet och populistiska. ${ }^{30}$ Populism definieras som uppfattningen att den grundläggande konflikten i samhället är den mellan en korrupt elit å ena sidan och folket å den andra. ${ }^{31}$

Sverigedemokraternas politiska framgångar var blygsamma under 1990-talet. De uppfattades inte som ett legitimt alternativ eftersom deras politik var allt för förknippad med en högerextremism med nazistiska rötter. ${ }^{32}$ Det rumsrena populistiska alternativet var i stället Ny Demokrati, som bildades år 1991 och kom in i riksdagen samma höst. I riksdagsvalet 1998 fick Sverigedemokraterna endast 0,4 procent av rösterna och år 2002 1,4 procent. År 2005 valdes Jimmie Åkesson till partiledare och nu ökade man ansträngningarna för att normalisera partiet. Partiet beskrev sig som ett "demokratiskt, nationalistiskt parti" inspirerat av den socialdemokratiska folkhemstanken och nationalkonservatism. I valet 2006 fördubblades stödet till 2,9 procent.

Det slutliga genombrottet kom i riksdagsvalet 2010, då Sverigedemokraterna 
fick 5,7 procent av rösterna och därmed platser i Sveriges riksdag. Väl inne isolerades man emellertid från övriga partiet, som vägrade samarbete eller någon form av samröre. Man fortsatte emellertid att växa: År 2014 fick man 12,9 procent av rösterna och i valet 2018 blev man tredje största parti med 17,5 procents stöd.

\section{Sverigedemokraternas väljare}

I dag finns en omfattande diskussion om Sverigedemokraternas identitet. En av de centrala frågorna är om det är rötterna $i$ fascism och nazism eller dagens officiella populistiska och socialkonservativa profil som framför allt definierar partiet? ${ }^{33}$ En annan diskussion gäller partiets väljare och vad som lockar dem till Sverigedemokraterna. Handlar det om en utbredd rasism och främlingsfientlighet i det svenska samhället, som kanaliseras genom Sverigedemokraterna, eller finns det andra orsaker - och i så fall vilka?

En del undersökningar tyder på att Sverigedemokraternas väljare är skeptiska till vad de ser som en allt för omfattande invandring - men inte nödvändigtvis på grund av rasism eller främlingsfientlighet, utan på grund av de negativa konsekvenser de menar att detta får för samhället som helhet, inte minst ekonomiskt. ${ }^{34}$ Markus Uvell har studerat Sverigedemokraternas väljare genom opinionsundersökningar och fokusgrupper, och identifierar tre väljartyper som dras till partiet. Den första kallar han den traditionelle arbetaren: en tidigare socialdemokratisk väljare som inte längre upplever sig representerad av sitt gamla parti. Medan globalisering och invandring hotar hans arbete och välfärd uppfattar han (oftast en han) att vänstern fastnat i diskussioner om könsroller, hbtq-rättigheter och andra kulturradikala frågor. Besviken vänder han sig därför till Sverigedemokraterna.
Den andra gruppen är den missnöjda läraren, som menar att Sverige präglas av ett tilltagande kaos knutet till invandringen, något som tydligast märks i klassrummet. Slutligen finns kvinnan i vården, som oroar sig över att invandringen naggar på de redan knappa resurser som borde gå till välfärden. 35

Invandringen är naturligtvis en nyckelfråga för alla dessa grupper, eftersom den uppfattas hota arbete, skapa oreda och kosta pengar. Men Uvells poäng är att det inte är rasism eller idéer om vit överlägsenhet som driver väljare ditåt, utan ett antal konkreta problem som har med socioekonomisk trygghet och stabilitet att göra. De som röstar på Sverigedemokraterna uppfattar att detta är det enda parti som tar deras oro inför dessa problem på allvar.

Uvell noterar också att Sverigedemokraternas väljare i regel är mer konservativa än genomsnittsväljarna. Det kommer bland annat till uttryck i att de bejakar så kallade "traditionella könsroller" och är skeptiska till drastiska samhällsomvandlingar. De har också starkare förankring på landsbygden än genomsnittsväljarna. 36 De som röstar på Sverigedemokraterna påminner med andra ord om de brittiska väljare som författaren David Goodhart har kallat för "Somewheres", och som till skillnad från de mobila "Anywheres" karakteriseras av att de värderar "stability, familiarity and more parochial group and national attachments and generally do not thrive in education driven economies". 37

Goodharts analys pekar på att det hos denna väljargrupp finns ett generellt missnöje med ett globaliserat, postindustriellt samhälle som premierar flexibilitet och rörlighet. Här närmar vi oss den faktor som står i centrum för denna artikel, nämligen sambandet mellan senmodern 
alienation och högerpopulism. Statsvetarna Edgar Grande och Hanspeter Kriesi menar att de senaste decenniernas utveckling skapat en klyfta i moderna samhällen mellan globaliseringens "vinnare" och "förlorare". Somliga har haft enklare att anpassa sig till de nya ekonomiska och kulturella förutsättningarna, och också trivts i dem, medan andra känt sig främmande för dem. Den senare gruppen har också attraherats av högerpopulistiska partier, som framför allt har appellerat till deras "cultural anxieties".38 Grande och Kriesi påpekar att även om dessa förlorar ekonomiskt på globaliseringen, så sker alltså den politiska mobiliseringen av dem med hänvisning till kulturella förändringar. ${ }^{39}$ Återigen ser vi alltså att existentiella faktorer har en framträdande roll. Samtidigt skapar detta ett svårlösligt politiskt dilemma, för hur kompenserar man en grupp som uppfattar sig vara "kulturella förlorare"?

Is there a cultural equivalent to the welfare state which is compatible with the requirements of economic openness and political integration? In fact, some would argue there is not, a fact which would make advanced capital societies politically highly vulnerable. ${ }^{40}$

Men stämmer det att det inte går att göra något åt detta? Om min tes att personer som är regelbundna gudstjänstbesökare är mindre benägna att dras till populism och främlingsfientlighet, då skulle vitala kyrkor och ett levande civilsamhälle kunna utgöra ett annat alternativ än det nationalistiska erbjudandet om en kulturellt och etniskt homogen nationalstat. Precis som för hundra år sedan skulle det kunna mildra det moderna traumat.

\section{Högerpopulism och socialt kapital}

Känslan av trygghet och sammanhang är också relaterat till det som kallas socialt kapital, det vill säga de relationer och nätverk som en person har tillgång till. Robert Putnam identifierar tre typer av kapital i ett samhälle: Fysiskt kapital, alltså materiella resurser; humankapital, det vill säga utbildning och kompetens; samt socialt kapital. Det sistnämnda handlar om kontakter, samarbetsförmåga och tilllit mellan medborgarna. ${ }^{41}$ En viktig infrastruktur för detta är föreningslivet och det civila samhället. ${ }^{42}$

Enligt Tocqueville är det sociala kapitalet - även om han inte använder det begreppet - avgörande i ett demokratiskt samhälle:

Hos demokratiska folk är däremot alla medborgare oberoende och svaga. De förmår nästan ingenting av sig själv, och ingen av dem är i stånd att tvinga sina medmänniskor att vara honom behjälpliga. Om de inte lärde sig att bistå varandra av fri vilja skulle de följaktligen drabbas av vanmakt. ${ }^{43}$

Ett starkt social kapital ger människor möjligheten att förbättra sin levnadsstandard och kan också fungera som krockkudde när olyckan är framme. Nätverk har visat sig vara av stor betydelse när människor söker jobb, men möjliggör också för gemenskaper att tillsammans avhjälpa sådant som de uppfattar som en brist i samhället eller i sina liv. De kan till exempel trygghetsvandra, ordna snöröjningen på sin gata, underhålla en badplats eller hjälpa en sjuk vän med matlagning. Personer utan socialt kapital är mer utsatta för ekonomiska, politiska och kulturella samhällsomvälvningar - de är med Tocquevilles ord vanmäktiga. ${ }^{44}$ Detta borde också betyda att människor utan socialt kapital är mer benägna att attraheras av högerpopulism. Människor utan socialt kapital är också, enligt själva definitionen, mer isolerade, ensamma och maktlösa. Undersökningar visar också att 
ett engagemang i kyrkor eller föreningsliv korrelerar med hög tillit, medan brist på sådan tillit kännetecknar högerpopulistiska väljare. ${ }^{45}$ Att delta aktivt i civilsamhället kan också innebära en möjlighet att möta och samverka med människor av olika slag. Denna övning i att leva med skillnad kan leda till att pluralism och mångkultur i samhället upplevs som mindre hotfullt. ${ }^{46}$

Sambandet mellan ett svagt socialt kapital och högerpopulism har studerats i ganska liten grad, och såvitt jag har kunnat finna inte alls när det gäller Sverige. ${ }^{47}$ Det finns emellertid några internationella studier som visar att personer som är aktiva i civilsamhället är mindre benägna att rösta på populistiska partier. Den ena är en kvantitativ studie av Europa och Sydamerika, där en italiensk forskargrupp drar slutsatsen att ett aktivt engagemang i civilsamhälle och föreningsliv möjligen med undantag för fackföreningar - gör personer mindre benägna att rösta på högerpopulistiska partier.48 I en liknande studie av det amerikanska valet år 2016 kommer Paola Giuliano och Romain Wacziarg fram till att det finns "a robust negative relationship between social capital and various measures of preferences for Donald Trump". ${ }^{49}$ I studier av nederländska väljare har Hilde Coffé påvisat samband mellan svagt socialt kapital och högerpopulistiska politiska sympatier. 50 Undersökningar av svenska förhållanden visar också att stödet för Sverigedemokraterna är starkt i de grupper där civilsamhällesengagemang och socialt kapital generellt är svagt: bland unga män, på landsbygden och bland lågutbildade. 51

En fråga som ibland lyfts är om det är möjligt att generalisera kring socialt kapital och civilsamhällesengagemang. 52 I sin klassiska studie Att bowla ensam visar
Putnam hur socialt kapital är ovärderligt för demokrati och tillit, men konstaterar också att det "kan styras till illvilliga, antisociala syften".53 Även om man kan argumentera för att socialt kapital och civilsamhällesengagemang har potentiellt goda effekter, så går det inte heller att förneka att gemenskaper kan röra sig i skilda riktningar och odla olika typer av ideal. Det gäller också politiskt.54 Det finns siffror som tyder på att personer som är engagerade i fackföreningar är mer benägna att rösta på populistiska partier. ${ }^{55}$ I USA hör väljare som tillhör vita evangelikala kyrkor till dem som starkast slutit upp bakom Trump, och det finns också studier som indikerar att kyrkobesökare som identifierar sig som nationell majoritet har en benägenhet att rösta på högerpopulistiska partier också i Europa. ${ }^{56}$ Samtidigt visar en rad studier att kyrkligt engagemang gör väljare mindre benägna att rösta på högerpopulistiska partier. ${ }^{57}$ Vilken riktning en gemenskap eller en rörelse tar handlar alltså om ett samspel av flera faktorer. Men de svenska kyrkorna, och inte minst frikyrkorna, tycks vara en civilsamhällesorganisation som gör väljare mindre benägna att rösta på Sverigedemokraterna. ${ }^{58}$

\section{Sverigedemokraterna och de kristna väljarna}

Oavsett vad man kallar Sverigedemokraternas ideologi - fascistisk, främlingsfientlig, populistisk eller socialkonservativ - så är det tydligt att nationen och nationell homogenitet står i centrum för den. I sitt partiprogram skriver de:

I likhet med stora delar av den tidiga, europeiska socialkonservativa rörelsen ser Sverigedemokraterna nationalismen som det enskilt viktigaste verktyget $\mathrm{i}$ arbetet med att bejaka den gemensamma identiteten och samhällets inre solidaritet. ${ }^{59}$ 
Kristendomen betraktas som ett redskap i arbetet för att skapa denna homogena nation. Den kristna tron, inte minst Svenska kyrkan, beskrivs som en del av den svenska nationella identiteten: "Sverige har varit ett kristet land i över tusen år. Kristendomen är intimt sammanvävd med den svenska kulturen och identiteten." Kristendomen bör därför "inneha en särställning i förhållande till andra religioner i Sverige".60 Mot denna bakgrund kunde man antagit att partiet uppfattas som särskilt attraktivt av just kristna väljare. Men som statsvetaren Magnus Hagevi visat är detta inte fallet. Sverigedemokraterna har konsekvent lägre stöd bland regelbundna gudstjänstbesökare än bland vanliga väljare - ja, mycket lägre, faktiskt. I VALU-undersökningen 2010 fick Sverigedemokraterna stöd av 2 procent av regelbundna kyrkobesökare, vilket kan jämföras med 6 procent av väljarna totalt. I Linnéuniversitetets mätning från 2014 fick Sverigedemokraterna 12 procent i väljarkåren generellt, men endast 3 procent bland gudstjänstbesökare.61 I den stora VALU-undersökningen samma år fick Sverigedemokraterna hälften så stort stöd (4 procent) bland gudstjänstbesökare som i väljarkåren generellt. Till 2018 års val hade stödet ökat, men låg fortfarande under hälften av rikssnittet: 9 procent av regelbundna kyrkobesökare angav att de röstade på Sverigedemokraterna, medan den genomsnittliga siffran var 19 procent. 62

Vad beror detta på? En del hävdar att orsaken är att kyrkliga väljare i högre utsträckning röstar på Kristdemokraterna, men Hagevi visar att det inte är hela förklaringen. Han har analyserat värderingar i den här gruppen, och noterar att frikyrkliga väljare har en mer positiv syn på invandring och mångkultur än genomsnittet: "individuals who are regu- lar free church goers tend to have comparatively positive opinions towards refugees and towards Sweden as a multicultural society."63

Det finns flera förklaringar till detta. Till att börja med har det historiska rötter i baptisters och andra frikyrkligas kamp för religionsfrihet och mot ett statligt religiöst förtryck sedan 1800-talet. ${ }^{64}$ Detta arv gör att frikyrkliga också i dag är måna om att värna religiös mångfald, även för människor från andra traditioner - till exempel muslimer. Frikyrkliga väljare är, som Hagevi noterar, exempelvis mer positiva än genomsnittet till ett mångkulturellt samhälle och de vill inte heller ha några förbud mot byggandet av moskéer. De är med andra ord mindre benägna att uppfatta upplösningen av den kulturella homogeniteten som ett existentiellt hot, utan ser den snarare som en förutsättning för att de själva ska kunna existera och etablera sina gemenskaper. ${ }^{65}$

Det finns också ett arv av internationell solidaritet i de svenska frikyrkorna, som tidigt kom att ägna sig åt mission och nödhjälpsarbete utanför Sveriges gränser. I samband med den stora flyktingkrisen år 2015 märktes styrkan i dessa värderingar genom det diakonala engagemanget för migranter hos många kyrkor. En stor del av församlingar i såväl frikyrkorna som Svenska kyrkan engagerade sig på olika sätt i mottagandet. De ordnade härbärgen, läxhjälp, språkkaféer eller stöttade på andra sätt. Här spelade den bibliska uppmaningarna att välkomna främlingen och flykten en stor roll för att motivera. ${ }^{66}$ Det är också intressant att notera att när Kristdemokraterna antog en mer restriktiv flyktingpolitik sjönk stödet för dem markant i den frikyrkliga väljarkåren. 67

Studerar man Sverigedemokraternas väljare finner man att de omfamnar kris- 
tendomen som en slags kulturell eller civilisatorisk identitet, men samtidigt är tämligen sekulariserade när det kommer till personlig tro och engagemang. 83 procent av partiets väljare instämmer i påståendet att Sverige är ett kristet land, och att "det är kristendomen som är normen”, vilket är långt över genomsnittet på omkring 50 procent. Men frågar man dessa väljare om de själva tror på Gud svarar bara 22 procent ja - och det är en bra bit under genomsnittet på 27 procent. Faktum är att Sverigedemokraternas väljare tillhör de mest sekulära av alla. Bara bland Vänsterpartiets och Liberalernas väljare är det färre som tror på Gud - 13 respektive 20 procent. Och bland dem som svarar tvärt nej på frågan om de tror på Gud, det vill säga inte väljer svaret "vet ej”, ligger Sverigedemokraternas väljare allra högst: 58 procent. 68

Kristen identitet, men inte kristen tro så kan Sverigedemokraternas religiösa profil beskrivas. Sverigedemokraternas nationalism är ett uttryck för kristendom förvandlad från tro till ideologi, och från personligt engagemang till kollektiv identitet. Det finns resultat som indikerar att sekularisering ökar risken för främlingsfientligheten bland vissa väljargrupper, vilket leder till en skepsis mot invandring och mångkultur. ${ }^{69}$ Men orsakskedjan skulle också kunna vara något annorlunda: sekulariseringen leder till existentiell osäkerhet, vilket vissa försöker möta genom en kulturell och nationell homogenitet som står i motsats till pluralism och mångkultur. Nationen tar kyrkans plats som det som ska ge människan mening, trygghet och sammanhang. Som historikern John Bossy formulerat det: Det heliga migrerar från kyrkan till nationalstaten. ${ }^{70}$

\section{Populismens existentiella dimensioner}

Tesen i denna artikel har varit att populismens genomslag inte bara handlar om ekonomiskt missnöje eller främlingsfientlighet, utan att den också har kulturella och existentiella orsaker. En orsak till dess genomslag är upplevelsen av förlust av sådant som pengar inte kan mäta: trygghet, traditioner, gemenskap, en känsla av tillhörighet. Att denna typ av alienation är ett inslag i moderniteten, och inte minst $\mathrm{i}$ senmoderniteten, är något som en rad teoretiker och forskare påpekat länge: Rousseau på 1700-talet, Marx och Tocqueville på 1800-talet, Weber och Durkheim på 1900-talet och slutligen till Zygmund Bauman och Charles Taylor i vår tid.

Om detta stämmer borde man kunna se att högerpopulistiska partier försöker fånga upp dessa känslor. En sådan ambition är också tydlig i Sverigedemokraternas retorik, även om det är något som ganska sällan uppmärksammas. Partiets slogan är "Trygghet och tradition" och i partiprogrammet återkommer existentiella termer som gemenskap, värdighet, sammanhållning och respekt regelbundet. Under sitt tal till nationen som sändes på Sveriges Television i maj 2018 hann Jimmie Åkesson nämna orden 'sammanhållning', 'tillit', 'samhörighet', 'trygghet' (två gånger) och 'hemkänsla' redan under talets första minut. Detta är inte skilt ifrån nationalism och invandringskritik i partiets program och retorik, utan sammanhållning, trygghet och gemenskap beskrivs som frukten av nationell homogenitet. Som Elgenius och Rydgren konstaterar: "Swedish nationalism is therefore offered as a remedy to restore authenticity, (ethnic and cultural) homogeneity and social solidarity." 71

Högerpopulismen adresserar alltså en 
djup mänsklig längtan efter sådant som varken individualistiskt oberoende eller den anonyma, kollektiva staten kan tillhandahålla: längtan efter gemenskap och att få höra till. Den svarar på behovet av sådana värden genom att erbjuda en mer solid modernitet i form av en nationalstat präglad av kulturell och etnisk homogenitet. Detta är något annat än att betrakta väljarna som individer som bara vill ha fler valmöjligheter, några rättigheter till och lite mer pengar på fickan. Eftersom människan inte bara är en autonom individ som förverkligas genom oberoende, utan en social varelse som söker gemenskap, finns mycket att vinna för ett parti som kan fånga upp denna längtan i ett samhälle där alienation och fragmentisering är utbredd. Högerpopulismen har insett detta: Det är en politisk rörelse med en existentiell klangbotten.

\section{Kyrkor och politik i den flytande moderniteten: Teopolitiska reflexioner}

Jag menar emellertid att högerpopulismens erbjudande inte kan råda bot på den senmoderna alienationen, för nationen kan inte fylla människas existentiella behov. Nationen är inget hem, utan en föreställd gemenskap (imagined community), som statsvetaren Benedict Anderson formulerat det. ${ }^{72} \mathrm{Vi}$ kan inte känna, inte ens träffa, alla medborgare i nationen Sverige. Nationalstaten är ett ramverk som kan ordna vissa saker, men människan kan aldrig kunna finna den gemenskap hon törstar efter i nationalstaten. Teologiskt kan drömmen om att den nationella gemenskapen ska kunna råda bot på vår ensamhet betraktas som ett exempel på att en god och naturlig längtan förvrids när den riktas mot ett felaktigt mål.

Den vanligaste kritiken mot nationalstaten i dag är att den är för smal: att den drar gränser, stänger människor ute och ställer folk mot folk. Det är sant - men sett ur en annan synvinkel är nationen också för bred. Den är för stor för att kunna utgöra ett hem. Människan behöver en plats på jorden, ett hörn där vi känner oss hemma. Vi blomstrar i gemenskap med människor som inte bara vagt känner igen oss, utan faktiskt vet vilka vi är. Vi behöver finnas bland personer som saknar oss om vi skulle försvinna, och som dyker upp på vår begravning den dag vi dör.

Det är riktigt att vi behöver vara något mer än "medborgare" i den stora staten eller "konsumenter" på den globala marknaden. Men den gemenskap vi längtar efter kan inte komma inte uppifrån, genom att vi hakar i gigantiska, nationella projekt. Det innebär att politiker inte kan servera gemenskap uppifrån, men däremot de kan bereda rum för dem så att de kan växa nerifrån. För gemenskaper måste, för att bli konkreta och levande, växa underifrån. ${ }^{73}$

Det är här kyrkorna kommer in, för inte minst genom sina lokala församlingar kan de vara ett svar på denna längtan. Det är också en del av förklaringen till att kyrkliga väljare inte attraheras av Sverigedemokraternas löften och retorik. De existentiella behov som populismen gör anspråk på att kunna fylla möts redan av de lokala församlingarna och den vidare kyrkliga gemenskap som dessa väljare finns i. Här finns gemenskap, samhörighet, tillit, sammanhållning och hemhörighet.

Då och då hör man personer som hävdar att kristendomen skulle ha framtiden för sig bara den gav upp de sociala gemenskaperna - församlingarna - och i stället antog en privat och mystisk form, mer anpassad till den moderna svenskens individualistiska spiritualitet. Men då har 
man missförstått både kyrkans och människans natur. För kristendomen lanserades inte som en lära eller en global organisation i första hand, utan växte fram som ett nätverk av lokala gemenskaper. Församlingar där människor levde ansikte mot ansikte. ${ }^{74}$

Här fanns gemenskaper som svarade på människans längtan efter att vara en del av ett vi. Det var samma struktur som gjorde att frikyrkorna kunde fungera som krockkuddar när Sverige tog steget in i moderniteten: församlingarna gav människor gemenskap och tillhörighet i en tid som samtidigt präglades av storskalighet och fragmentisering. ${ }^{75}$ Den svenska demokratin växte alltså inte fram tack vare autonoma individer, utan via små gemenskaper. "Sverige är en studiecirkeldemokrati” sa en gång statsminister Olof Palme. Tocqueville gjorde samma iakttagelse när han konstaterade att den amerikanska demokratin vilade på konsten att sammansluta sig. ${ }^{76}$

Men i dagens flytande modernitet, där alla våra åtaganden är villkorade, löses denna typ av gemenskaper upp. Det skapar ett politiskt och existentiellt tomrum, ett samhälle med alienerade individer som blir lätta byten för profittörstande företag och populistiska politiker. Som Yuval Harari konstaterar: "Stater och marknader som består av alienerade individer kan mycket lättare ingripa i sina medlemmars liv än stater och marknader som består av starka familjer och lokalsamhällen."77

En orsak till högerpopulismen fram- gångar är alltså att moderniteten upplevs som ett trauma genom förlusten av sammanhang. Denna tendens förstärks när individualismen går från att vara ett politiskt skydd för den enskilde, till en kulturellt ideal. Men den politiska lösningen bör inte, menar jag, vara att placera en kultur, en ideologi eller en religion i centrum, och tvinga den på alla medborgare. Dels för att det inte fungerar, dels för att nationalisternas svar skulle innebära att vi gav upp religionsfrihet och demokrati.

Ett bättre alternativ är att nationen fylls av en mängd traditioner och rörelser. Men då behöver politiker betrakta religiösa traditioner som en tillgång, och kyrkorna förstå att de spelar en viktig roll i samtiden. ${ }^{78}$

Inte genom att utöva makt, att kräva absolut uppslutning bakom deras idéer och ideal utan genom att leva ett aktivt och engagerat församlingsliv. Då skapas platser där människan kan finna den gemenskap, samhörighet och det hem som hon behöver.

För människan lever inte av oberoende allena, utan behöver gemenskap, tillhörighet och riktning. Men i en pluralistisk tid måste sådana saker komma nerifrån de kan inte tryckas på oss uppifrån. Kyrkorna måste vara beredda att axla denna uppgift. Inte för att de får sitt existensberättigande genom att de stöttar demokratin, utan för att det är i linje med kyrkans grundläggande uppdrag: att välkomna människor att bli lemmar i Kristi kropp. ${ }^{79}$ 


\section{Noter}

1 Förståelsen av högerpopulism i denna artikel följer Cas Muddes definition av fenomenet. Mudde menar att radikala populistiska högerpartier kännetecknas av att de är auktoritära, nativistiska - det vill säga betonar vikten av nationell homogenitet - och populistiska. Se Cas Mudde, "Fighting the System? Populist Radical Right Parties and Party System Change", Party Politics 20, nr 2 (2014), 217-226 samt Cas Mudde, "The Populist Zeitgeist", Government and Opposition 39, nr 4 (2004), 541-563.

2 För diskussioner kring detta samband i europeiskt perspektiv, se Kathleen A. Montgomery och Ryan Winter, "Explaining the Religion Gap in Support for Radical Right Parties in Europe", Religion and Politics 8, nr 2 (2015), 379-403. Andrea Bohman och Mikael Hjerm, "How the Religious Context Affects the Relationship Between Relgiousity and Attitudes Towards Immigration”, Ethnic and Racial Studies 37, nr 6 (2014), 937-957. Pascal Siegers och Alexander Jedinger, ”Religious Immunity to Populism: Christan Religiosity and Public Support for the Alternative for Germany", German Politics (2020), https://doi.org/10.1080/09644008.2020.1723002. Kamil Macrinkiewicz och Ruth Dassonneville, “Do Religious Voters Support Populist Radical Right Parties?”, Party Politics 2021, 1-3. För en studie som hävdar motsatsen, se Pippa Norris och Ronald Inglehart, Cultural Backlash: Trump, Brexit, and Authoritarian Populism (Cambridge: Cambridge University Press, 2019). För Sverigedemokraternas försök att knyta an till kristendom, se exempelvis Hans Morten Haugen, "Sweden Democats' Appeal to Christianity: Can Religious Identity Politics Win Genereal Support?", Nordic Journal of Religion and Society 28, nr 1 (2015), 77-94.

3 För frikyrkliga väljares benägenhet att välja bort Sverigedemokraterna, se Magnus Hagevi, ”Xenophobic Opinion, a Populist Radical Right Party, and Individuals with Different Religious Contexts in Sweden", Journal of Church and State 60, nr 3 (2018), 449-471. För en analys av Sverigedemokraternas retorik och centrala budskap, se Gabriella Elgenius och Jens Rydgren, ”Frames of Nostalgia and Belonging: The Resurgence of Ethno-Nationalism in Sweden", European Societes 21, nr 4 (2019), 583-602.

4 Se t.ex. Dani Rodrik, "Populism and the Economics of Globalization”, Journal of Interntional Business Policy 1, nr 1-2 (2018), 12-33.

5 Edgar Grande och Hanspeter Kriesi, ”Transformative Power of Glocalization and the Structure of Political Conflict in Western Europe" i Political Conflict in Western Europe, red. Hanspeter Kriesi et al (Cambridge: Cambridge University Press, 2012), nr 4, 15-17.

6 En idé- och mentalitetshistorisk översikt på detta tema återfinns i Pankaj Mishra, Age of Anger: A History of the Present (London: Allen Lane, 2017). Se även Joel Halldorf, Gud: Återkomsten (Örebro: Libris, 2018), 78-102.

7 Charles Taylor talar om "the malaise of modernity", se Charles Taylor, The Malaise of Modernity (Toronto: House of Anansi Press, 1997). För en översikt över modernitetskritik, se Steven B. Smith, Modernity and Its Discontents (New Haven \& London: Yale University Press, 2016).

8 Zygmund Bauman, Liquid Modernity (Cambridge: Polity Press, 2000), 14, 61, 106.

9 Alexis de Tocqueville, Om demokratin in Amerika, bok 1 \& 2 (Stockholm: Atlantis, 1997). Se exempelvis bok 1 , sidorna 84, 263-269, 351 samt bok 2, sidorna 149-154.

10 Med kyrkligt aktiva avses här framför allt regelbundna gudstjänstbesökare i kristna kyrkor. Här finns en skillnad mellan olika samfund och traditioner, bland annat de klassiska frikyrkorna och Svenska kyrkan, men det finns inte utrymme att ta hänsyn till den här.

11 Pankaj Mishra, Age of Anger: A History of the Present (London: Allen Lane, 2017). För en diskussion kring Mishras bok, se Roundtable Review, vol XX, nr 44 (2019) där en rad historiker responderar på hans tes.

12 Francis Fukuyama, The End of History and the Last Man (Harmondsworth: Penguin, 1992). För ett annat exempel på denna standardberättelse, se Christian Welzel och Ronald Inglehart, Modernization, Cultural Change, and Democracy: The Human Development Sequence (Cambridge: Cambridge University Press, 2005).

13 Ett arbete som utifrån teologiska motiv lyfter fram de problematiska sidorna av moderniteten är Brad Gregory, The Unintended Reformation: How a Religious Revolution Secularized Society (Cambridge: Belknap Press of Harvard University Press, 2012).

14 Mishra, Age of Anger, 23, 26-27. För korrelationen mellan modernisering och psykisk ohälsa, inklusive analyser av orsakerna till detta, se Roland Paulsen, Tänk om: En studie i oro (Stockholm: Bonnier, 2020).

15 Smith, Modernity and Its Discontents.

16 Se David Tjeder, The Power of Character: Middle-Class Masculinities, 1800-1900 (Stockholm: Stockholms Universitet, 2003).

17 Mishra, Age of Anger, 89.

18 Friedrich Nietzsche, Ecce Homo (Lindon: T. N. Foulis, 1911), 132.

19 Max Weber, The Protestant Ethic and the Spirit of Capitalism (London \& New York: Routledge, 2001), 86.

20 Hannah Arendt, The Origins of Totalitarianism (New York: Harcourt Brace \& Company, 1973), 317.

21 Simone Weil, The Need for Roots (London: Routledge 2002), 114. Alan Jacobs har ett utmärkt kapitel om West i sin bok Original Sin (New York: HarperCollins, 2008), 211-238, se särskilt sidorna 226-227.

22 Sven Lundkvist, Folkrörelserna i det svenska sambället (Uppsala: Uppsala universitet, 1977), 223.

Halldorf, Gud: Återkomsten, 82-83. 
23 Yuval Noah Harari, Sapiens: En kort historia över mänskligheten (Stockholm: Natur \& Kultur, 2015), 347-348.

24 Yuval Levin, The Fractured Republic: Renewing America's Social Contract in the Age of Individualism (New York: Basic Books, 2016), 97. Se även Markus Uvell, Bakslaget: Radikalt etablissemang, koservativa medborgare (Stockholm: Timbro, 2018), 64-65.

25 Mishra menar att detta inte bara påverkar politiken i väst, utan globalt, se Mishra, Age of Anger, 32.

26 För behovet av gemenskap ("social samhörighet") för lycka och välmående, se t.ex. Putnam, Bowling Alone, 276-279, 344-353.

27 Yvonne Hirdman, Att lägga livet till rätta (Stockholm: Carlsson, 1989), 27.

28 Joel Halldorf, "Populism as Existentialism: The Sweden Democrats and the Longing for Connection" i Is God a Populist, red. Susan Kerr (Oslo: Frekk Forlag, 2020).

29 För Sverigedemokraternas framväxt och historia, se till exempel Ann-Cathrine Jungar och Anders Ravik Jupskås, "Populist Radical Right Parties in the Nordic Region: A New and Distinct Party Family?", Scandinavian Political Studies 37, nr 3 (2014), 215-238. Anna-Lena Lodenius och Per Wikström, Vit makt och blågula drömmar: Rasism och nazism i dagens Sverige (Stockholm: Natur \& Kultur, 1997). Jens Rydgren, From Tax Populism to Ethnic Nationalism: Radical Right-Wing Populism in Sweden (New York \& Oxford: Berghahn Boks, 2006).

30 Mudde, "Fighting the System? Populist Radical Right Parties and Party System Change".

31 Cas Mudde, "The Populist Zeitgeist".

32 Elgenius och Rydgren, "Frames of Nostalgia and Belonging", 7: "The fact that the Sweden Democrats

failed to present a respectable façade is one main reason as to why Sweden lacked an electorally successful radical right-wing party until the 2010 general national election."

33 Henrik Arnstad, "Fascism - eller något annat?" i Sverigedemokraternas svarta bok, red. Madelen

Axelsson \& Kristian Borg (Stockholm: Verbal förlag). En utförlig analys av budskap och retorik återfinns i Elgenius och Rydgren, "Frames of Nostalgia and Belonging”. De menar att Sverigedemokraterna har lämnat den gamla högerextrema politiska visionen med tydliga inslag av rasism och antisemitism och i stället formulerat en som kombinerar etno-nationalism och etablissemangskritisk populism. Deras slutsats är emellertid att föreställningar om biologiska och nationella essenser även präglar denna senare vision.

34 Det har konstaterats en korrelation mellan uppfattningen att samhällets eller den privata ekonomin utvecklats negativt, och stöd för Sverigedemokraterna. Se Magnus Hagevi, Den svenska väljaren 2014 (Lund: Gleerups, 2015), 135.

35 Markus Uvell och Erik Meier, Folkhemspopulismen: Berättelsen om Sverigedemokraternas väljare (Stockholm: Timbro, 2010), 37-47. Uvell, Bakslaget, 141-145.

36 Uvell, Bakslaget, 144-145.

37 David Goodhart, "Britons Need to Rediscover the Ties that Bind", The Guardian, 8 oktober 2017. Se även David Goodhart, The Road to Somewhere: The Populist Revolt and the Future of Politics

(London: Hurst \& Company, 2017).

38 Grande och Kriesi, "Transformative Power", 4.

39 Grande och Kriesi, "Transformative Power", 15: "We would like to suggest that the cultural and political dimensions of the new divide are politically more consequential than the economic dimension."

40 Grande och Kriesi, ”Transformative Power", 17.

41 Robert Putnam, Den ensamme bowlaren: Den amerikanska medborgarandans upplösning och förnyelse (Stockholm: SNS förlag, 2001), 18.

42 Se t.ex. Lars Trägårdh et al, Civilsambället klämt mellan stat och kapital: Välfärd, mångfald, framtid (Stockholm: SNS Förlag, 2013).

43 Alexis de Tocqueville, Om demokratin i Amerika, bok 2, 151.

44 Den klassiska studien av socialt kapital är Putnam, Den ensamme bowlaren. Se särskilt sidorna 18-26 för en diskussion av begreppet.

45 För bristande tillit hos Sverigedemokraternas väljare, se till exempel Hagevi, Den svenska väljaren 2014, 135. För en diskussion om bristande tillit i populismen generellt, se Catherine Fieschi och Paul Heywood, "Trust, Cynicism and Populist Anti-Politics”, Journal of Political Ideologies 9, nr 3, 289-309. Sambandet mellan tillit och religiöst engagemang har undersökts i Robert Putnam och David Campbell, American Grace: How Religion Divides and Unites Us (New York: Simon \& Schuster, 2010), 458-462.

46 Jfr t.ex. Bauman, Liquid Modernity, 106: "The ability to live with differences, let alone to enjoy such living and to benefit from it, does not come easily and certainly not under its own impetus. The ability is an art which, like all arts, requires study and exercise." För ett sådant perspektiv på civilsamhället, se Luke Bretherton, Christianity \& Contemporary Politics (Oxford: Wiley-Blackwell, 2010).

47 I en undersökning från 2009 tittar professor Jens Rydgren på sambandet mellan socialt kapital och högerextremism i Belgien, Danmark, Frankrike, Norge och Schweiz. Hans slutsats då var att ett klart sådant samband inte kunde beläggas, men att det fanns en viss tendens till att människor som är aktiva i frivilligorganisationer är mindre benägna att rösta på högerextrema partier. Här behövs dock, konstaterar Rydgren, mer data och inklusive en differentiering när det gäller vilken typ av organisationer personer deltar i, bland annat om de är horisontella eller hierarkiska. Se Jens Rydgren, "Social Isolation? Social Capital and Radical Right-Wing Voting in Western Europe”, Journal of Civil Society 5, nr 2 (2009), 139-140. 
48 Tito Boeri, Prachi Mishra, Chris Papagorgiou, Antonio Spilimbergo, "Populism and Civil Society", IMF Working Paper, 2018.

49 Paola Giuliano och Romain Wacziarg, "Who Voted for Trump? Populism and Social Capital",

IZA Institute of Labor Economics, augusti 2020.

50 Hilde Coffé och Benny Geys, "Participation in Bridging and Bonding Associations and Civic Attitudes: Evidence from Flanders", Voluntas: international Journal of Voluntary and Nonprofit Organizations 18 (2007), 385-406 samt Hilde Coffé et al, "Fertile Ground for Extreme Right-Wing Parties: Explaining the Vlaam Blok's Electoral Success", Electoral Studies 26, nr 1, 142-155.

51 Halldorf, Gud: Återkomsten, 84. Se Anders Sannerstedt, "Sverigedemokraternas sympatisörer" i Mittfåra och mariginal: SOM-undersökning 2013, red. Annika Bergström och Henrik Oscarsson (Göteborg: SOM-institutet, 2014). I en studie av väljare i Nederländerna noterar forskare att högerpopulistiska partier är "particularly successful in municipalities with a small network of social organisation". Se Hilde Coffé et al, "Fertile Ground for Extreme Right-Wing Parties".

52 Jens Rydgren, "Social Isolation?", 141.

53 Robert Putnam, Den ensamme bowlaren, 22.

54 Coffé och Gey, "Participation in Bridging and Bonding Associations and Civic Attitudes".

55 Tito Boeri, Prachi Mishra, Chris Papagorgiou, Antonio Spilimbergo, "Populism and Civil Society".

56 Skillnaden mellan vita evangelikaler och svenska frikyrkliga väljare i detta avseende tycks bland annat handla om huruvida man identifierar som majoritet eller minoritet. Om man förstår sig som majoritet leder en växande mångfald lättare till den typ av kulturella ångest som tycks kunna drabba sekulära svenska väljare. Jfr Magnus Hagevi, ”Evangelikaler i svensk och amerikansk politik” i Religion och politik, red. Magnus Hagevi (Malmö: Liber, 2005) samt Joel Halldorf, ”A Tale of Two Evangelicalisms”, Breaking Ground, oktober 2020. För ett visst samband - om än svagt - mellan religiösa väljare och högerpopulism, se Wouter Van der Brug och Meindert Fennema, "Protestant or Mainstream? How the European anti-immigrant parties have developed into two separete groups by 1999", European Journal of Political Research 42, nr 1 (2003), 55-76. Enligt Norris är dock det generella sambandet motsatt, det vill säga högerpopulistiska partier har svagare stöd bland religiösa väjare, se Pippa Norris, Radical Right: Voters and Parties in the Elecotral Market (Cambridge: Cambridge University Press, 2005).

57 Kamil Macrinkiewicz och Ruth Dassonneville, "Do Religious Voters Support Populist Radical Right Parties?”. Kathleen A. Montgomery och Ryan Winter, "Explaining the Religion Gap in Support for Radical Right Parties in Europe". Andrea Bohman och Mikael Hjerm, "How the Religious Context Affects the Relationship Between Relgiousity and Attitudes Towards Immigration”. Pascal Siegers och Alexander Jedinger, "Religious Immunity to Populism: Christan Religiosity and Public Support for the Alternative for Germany".

58 Samma sak verkar vara fallet i Nederländerna, och där pekar forskare också på de sociala nätverken och kristna praktikerna som avgörande, se Peter Achterberg och Jeroen van de Waal, "One Nation Without God? Post-Christian Cultural Conflikt in the Netherlands" i Paradoxes of Individualization, red. Dick Houtman et al (New York: Routledge, 2016).

59 Sverigedemokraternas partiprogram (2018), "Sverigedemokraterna och nationalismen".

60 Sverigedemokraternas partiprogram (2018), "Sverigedemokraterna och religionen".

61 För närmare kommentarer kring religionens påverkan på valet 2014, se Hagevi, Den svenska väljaren 2014, 50-53, 182.

62 Magnus Hagevi, "Samhällsförändringarna bakom radikala populistiska partier" i Sverige, Sverige fosterland, red. Kjell-Åke Norquist. (Stockholm: Teologiska högskolan Stockholm och Studieförbundet Bilda, 2015). Joel Halldorf, Pentecostal Politics in a Secular World: The Life and Leadership of Lewi Pethrus (New York: Palgrave Macmillan, 2020), 259-260.

63 Hagevi, "Xenophobic Opinion”, 470.

64 Lydia Svärd, Väckelserörelsernas folk $i$ andra kammaren 1867-1911: Frikyrkliga och lågkyrkliga insatser $i$ svensk politik (Stockholm: Missionsförbundets förlag, 1954). Arne Rasmusson, "Kyrkan och kampen för ett bättre samhälle", Svensk Teologisk Kvartalsskrift 96, nr 2 (2020).

65 Halldorf, Pentecostal Politics in a Secular World, 259-260.

66 Kristina Hellqvist och Andreas Sandberg, En tid av möten: Arbetet med asylsökande och nyanlända $i$ Svenska kyrkans församlingar 2015-2016 (Uppsala: Svenska kyrkan, 2016).

67 Jacob Zetterman, "Stor undersökning: Så röstar de kristna väljarna”, Dagen, 31 maj 2018.

68 Uvell, Bakslaget, 66-74. Hagevi, Den svenska väljaren 2014, 51.

69 Peter Achterberg och Jeroen van de Waal, ”One Nation Without God” Jfr även professor Geoffrey C. Layman, "Where is Trump's Evangelical Base? Not in Church", Washington Post, 29 mars 2016.

70 Se vidare Joel Halldorf, Gud: Jakten. Existentiell svindel $i$ det 21: a arhundradet (Stockholm: Fri Tanke, 2020), 101-106. Jfr William Cavanaugh Migrations of the Holy: God, State, and the Political Meaning of the Church (Grand Rapids: Eerdmans, 2011).

71 Elgenius och Rydgren, "Frames of Nostalgia and Belonging", 16.

72 Benedict Anderson, Imagined Communities (New York: Verso, 2006).

73 Förslag till en sådan politik presenteras av många i dag. Förutom den tidigare nämnda Yuval Levin, se även George Monbiot, Out of the Wreckage (New York: Verso, 2017), 71-92. 
74 Se t.ex. Rodney Stark, The Triumph of Christianity: How the Jesus Movement Became the World's Largest Religion (New York: HarperOne, 2014).

75 Gunnar Hallingberg, Läsarna: 1800-talets folkväckelse och det moderna genombrottet (Stockholm: Atlantis, 2010). Jfr även Lundkvist, Folkrörelserna i det svenska sambället samt Halldorf, Gud: Återkomsten 76 Alexis de Tocqueville, Demokratin i Amerika 2.

77 Harari, Sapiens, 348.

79 Detta argument utvecklas i Halldorf, Gud: Återkomsten.

79 För ett teologiskt argument för demokrati, se Luke Bretherton, Christ and the Common Life: Political Theology and the Case for Democracy (Grand Rapids: Eerdman, 2019). 